\title{
Choral Intertemporality in the Oresteia ${ }^{1}$ Jonas Grethlein, Heidelberg
}

One of the most salient aspects of the chorus in Greek tragedy is its mediation between the play and the audience. Schlegel's view of the chorus as "ideal spectator" has recently been taken up and refined by Claude Calame, who argues that, besides embodying a specific group in the dramatic action, the chorus also merges the voices of the author and the audience. ${ }^{2}$ The mediation between the actors and the audience is obvious in the spatial position of the choreutae who, after the parodos, come to stand in the orchestra. Here, between the stage and the theatron, they sing, dance and follow the dramatic action. In this paper, I would like to turn to time and argue that, though less obviously than space, time is also crucial to the mediating function of the chorus. It is a commonplace that tragedy brings together a heroic past with the democratic present. ${ }^{3}$ While "heroic vagueness" marks the time of the action as different from the present of the performance, " "zooming-devices" establish links to the world of the spectators. ${ }^{5}$ The distance of the heroic world as well as polyphony allows tragedy to negotiate issues controversial in the polis of Athens. At first sight, the chorus, often representing marginal groups ${ }^{6}$ and using the Doric of Greek lyric in their songs, may seem to distance the action from the world of the audience. At the same time, the "song culture"7 of ancient Greece provides the audience with a frame in which choral songs have direct significance. In exploring the complex temporality of the Greek chorus, I would like to show that the choral odes contribute much to the dialogue between past and present enacted in tragedy, that intertemporality is an important aspect of the chorus' mediation.

My test-case will be the four songs of the chorus in Aeschylus' Agamemnon, complemented by the central stasimon of the Choephoroi and the ending of the Eumenides. The songs of the Agamemnon illustrate that, engaging in anachronies, the chorus set up a panopticon in which various levels of time intersect with one another (I). Through general reflections, the choreutae create a horizon of meaning that extends this panopticon to the present of the performance (II). The first stasimon of the Choephoroi and the ending of the Eumenides show further aspects of choral

\footnotetext{
${ }^{1}$ The Greek text of Aeschylus follows West 1998: the English text is based on Lattimore's translation in Grene 1953. I wish to thank Marianne Hopman and Renaud Gagné for their stimulating comments and suggestions.

2 Calame 1999, this volume.

${ }^{3}$ For a classic formulation of this position, see Vernant 1990.

${ }^{4}$ On the term "heroic vagueness", see Easterling 1997, who in an earlier article emphasizes the avoidance of anachronisms in Greek tragedy (1985).

${ }^{5}$ The term "zooming-device" was coined by Sourvinou-Inwood 1989. To give an example: In the Aeschylian Supplices, the assembly mentioned by Pelasgus, particularly the vote by show of hand (604, $607,621)$ is strongly reminiscent of democratic Athens and 'the ruling hand of the people' (' $\delta \eta \mu o v$

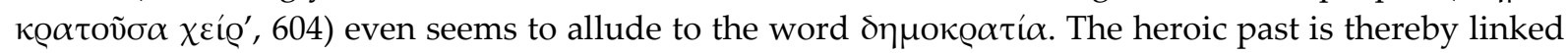
to the presence of the performance.

${ }^{6}$ This is emphasized by Gould 1996. See, however, also Foley 2003 on the fluidity of choral identity.

${ }^{7}$ Herington 1985: 3.
}

Published in: R. Gagné, M. Hopman (2013) Choral Mediations in Greek Tragedy, 78-99 
intertemporality, the former that choral songs can serve as a mise-en-abime: the relation between the dramatic action and myths invoked by the chorus mirrors the relation between the present of the performance and the past enacted on stage (III). At the end of the Eumenides, the special temporality of ritual makes the time of the play merge with the time of the performance (IV). Despite its traditional form, the chorus is crucial to the dialogue between "heroic vagueness" and democratic present staged in the theatre of Dionysus (V).

\section{Anachronies: a Panopticon of Times Past, Present and Future}

In a first step, I wish to demonstrate the temporal complexity of choral song concerning the sequence of its narrative. A dense net of anachronies, both to the past and the future, some explicit, others implicit, evokes different times to be seen in light of one another. The singing of the choreutae transcends the present of the action and delimits time. Given its length and richness, the parodos of the Agamemnon will be at the core of my exploration, but also the first and second odes furnish good examples for this aspect of choral intertemporality.

The parodos of the Agamemnon is the longest and arguably most complex choral song in extant tragedy. The dense metaphors and riddles have given scholars many a headache. The embedding of two long direct speeches, by Calchas and Agamemnon, is unique. ${ }^{8}$ Particularly complex is the ode's temporal organisation on which I shall focus for the purposes of this paper, but let me first sketch its content: In the first, anapaestic part of the parodos, the chorus starts with the Greek expedition to Troy, which is envisaged in an extended vulture simile (40-67). The statement that no form of sacrifice can turn away a fated end (68-71) leads the old Argives to a reflection on their own age which has made them childlike and prevented them from joining the expedition (72-82). They then address Clytaemnestra, inquiring about the reason for the sacrifices which are being made (83-103). The lyrical part of the parodos, probably starting with the arrival of the choreutae in their place in the orchestra, consists metrically of three parts which do not exactly map onto the structure at the level of content. In a dactylo-iambic triad (104-59), the chorus returns to the topic of the Trojan expedition and reports the omen at Aulis, two eagles feasting on a pregnant hare, which Calchas interpreted as a prediction of the capture of Troy, while also alerting the Greeks to the wrath of Artemis. The first three of four trochaic stanzas contain the so-called Hymn to Zeus, a reflection on the power of the highest god (160-83). A fourth trochaic stanza and three pairs of iambic-choriambic stanzas are then devoted to the narration of the sacrifice of Iphigenia and conclude the song with a reflection on the opaqueness of the future (184-257).

Seen as a whole, the parodos offers a chronological account of the departure of the Greek army to Troy. From the perspective of the characters, the chorus looks back to their past; if we view the action as taking place in "heroic vagueness", then the

\footnotetext{
${ }^{8}$ On direct speech in choral odes, see Bers 1997: ch. 1; Fletcher 1999: 31-2; Rutherford 2007: 17.
}

Published in: R. Gagné, M. Hopman (2013) Choral Mediations in Greek Tragedy, 78-99 
chorus engages with a past embedded in the past, a "plu-past". ${ }^{9}$ Interspersed with the report are comments of the choreutae on their present, as on their own old age (72-82) and on the sacrifices of Clytaemnestra (83-103), and general reflections, namely on the use of sacrifices (68-71), on the power of Zeus (160-83) and, finally, on the impossibility of divining the future (250-7). This entangling of the past with the present $^{10}$ comes to the fore in the speech of Calchas which is punctuated by the

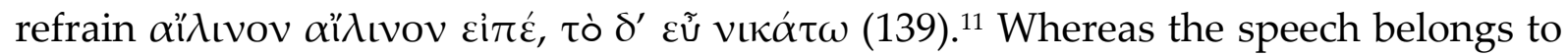
the past, the deictic center of the refrain is in the present.

In addition to this switching between past und present, several anachronies are embedded in the chronological account of the Greeks' departure. ${ }^{12}$ The pathos of Iphigenia's death, for example, is heightened by an analepsis to dinner-parties at Argos in which she participated. Iphigenia's joyful singing at Argos contrasts with

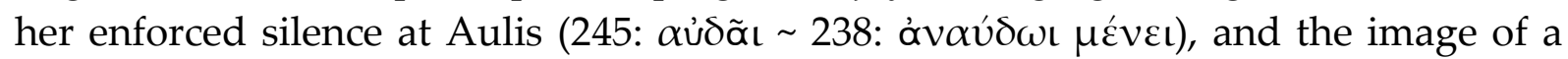
proper feast, first sacrifice, then dinner to be followed by a Paian which would lead to drinking, highlights the perversion of the sacrifice as which Iphigenia's death is envisaged. In implying the word "bull", the very rare adjective ó $\tau \alpha u ́ \emptyset \omega \tau o \varsigma ~(245)$ evokes the victim of proper sacrifices as a contrast. The flashback evokes a past even previous to the "plu-past" embedded in the heroic past, three levels of past being grafted upon one another.

More striking than this analepsis are leaps into the future. They can be divided into external and internal prolepses. ${ }^{13}$ While the former refer to events that, at least from the perspective of the chorus, are still to come, the latter constitute a future past, a time that is future at the level of the "plu-past", but already past for the chorus. The devouring of the pregnant hare by the two eagles is interpreted by Calchas as an omen predicting the fall of Troy (122-30). Ironically, this event is not only future for the Greeks at Aulis, but is also envisaged as future by the Argive elders, although it has just taken place. The audience already knows from the prologue that Troy has been captured, news that the chorus is going to learn in the epeisodion following upon the parodos.

Calchas predicts a further event which is a future past for the chorus (131-8):

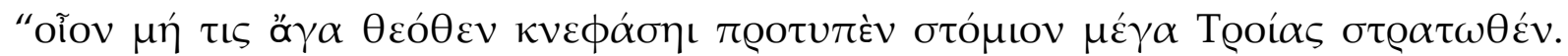

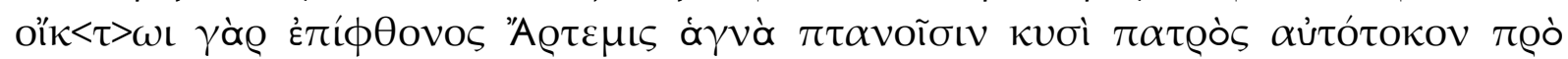

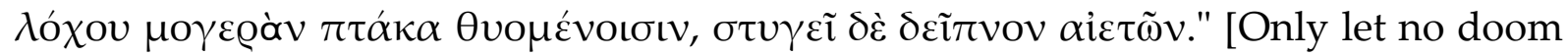
of the gods darken upon this huge iron forged to curb Troy - from inward. Artemis the undefiled is angered with pity at the flying hounds of her father eating the

\footnotetext{
${ }^{9}$ On the idea of a "plu-past", see the contributions to Grethlein / Krebs (eds.) 2011, which explore the "plu-past" in ancient historiography.

${ }^{10}$ Cf. Court 1994: 183, who speaks of a "Schwebezustand". See also Duchemin 1974: 123.

${ }^{11}$ On this refrain, see Moritz 1979: 196 that the two-sidedness is highly apt to reflect "an ambivalent situation in which the proportion of good to evil remains uncertain, and any good will almost certainly comes at the price of some ill".

${ }^{12}$ For a closer look at the temporal structure of 184-217, see Barrett 2007: 262-3.

${ }^{13}$ On external and internal prolepses, see Genette 1972: 109.
}

Published in: R. Gagné, M. Hopman (2013) Choral Mediations in Greek Tragedy, 78-99 
unborn young in the hare and the shivering mother. She is sick at the eagles' feasting].

Calchas goes on to elaborate on Artemis' care for young animals (140-4) and appeals to Apollo to "remedy" the Greeks when Artemis is calling for a "second sacrifice unholy, untasted" (150-1), which turns out to be the killing of Iphigenia, narrated by the chorus after the Hymn to Zeus. In this second part of Calchas' omen, the entanglement of different levels of time is particularly complex and has not failed to puzzle scholars. The killing of the pregnant hare adumbrates the future capture of Troy, especially the atrocities committed against the young, but nonetheless arouses Artemis' anger against the Atridae in the present and seems to necessitate the sacrifice of Iphigenia before the event signified by the omen has taken place. Present and future are tightly interwoven, partly in a causal, partly in a non-causal way. Semiotically speaking, the bird omen works as an indexical as well as an iconic sign. ${ }^{14}$ Through similarity, the killing of a hare by two eagles refers to the capture of Troy by the two Atridae (icon). At the same time, the feasting upon a pregnant hare angers Artemis who can only be appeased by the sacrifice of Agamemnon's daughter. The bird sign is linked to the death of Iphigenia in a cause-effect-relation and is therefore also indexical. ${ }^{15}$ If we assume that what the omen iconically signifies, that is, the fall of Troy, is the cause of its indexical significance, namely the sacrifice of Iphigenia, then causality is reversed, a later event causing an earlier one.

The semiotic complexity is heightened if we also take into account the first occurrence of birds in the parodos. Scholars have not failed to notice the correspondence between the eagle omen and the simile of the vultures in the

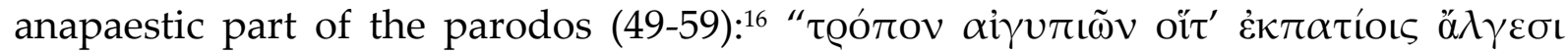

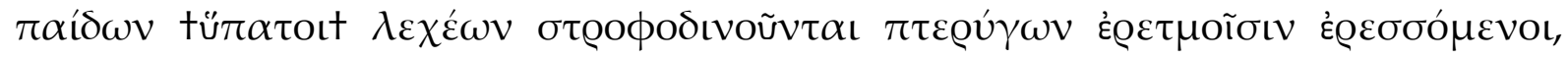

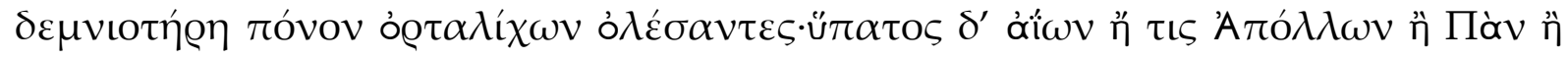

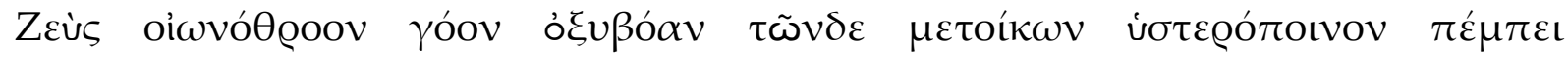

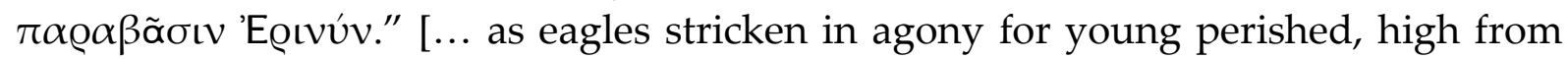
the nest eddy and circle to bend and sweep of the wings' stroke, lost far below the fledgelings, the nest, and the tendance. Yet someone hears in the air, a god, Apollo, Pan, or Zeus, the high thin wail of these sky-guests, and drives late to its mark the Fury upon the transgressors].

What I find striking is the direction of the semiotic process: first, the birds serve as a metaphor for the Atridae; then, they leave the discourse of language and become a sign in extra-linguistic reality, the bird omen, which finally transcends its status as mere signifiant when it angers Artemis and leads to the sacrifice of Iphigenia. In the course of the three stages, the sign arrogates to itself more and more

\footnotetext{
${ }^{14}$ I here draw on Pierce's concept of signs: an icon denotes an object by virtue of similarity, e.g. a portrait resembles the person portrayed; an index denotes an object through an actual connection as for example smoke derives from fire; in a third category, called symbol, the denotation is based on convention

${ }^{15}$ On Artemis' anger, see Peradotto 1969: 240-2; Gantz 1983: 73 with further literature.

${ }^{16}$ E.g. Lebeck 1971: 8.
}

Published in: R. Gagné, M. Hopman (2013) Choral Mediations in Greek Tragedy, 78-99 
the character of something real - a sign, it seems, is more than a sign. ${ }^{17}$ Not only does time make the process of signification unstable, but the border between signifiant and signifié, between sign and reality, between language and world becomes blurred. ${ }^{18}$

The simile of the vultures deserves closer attention. Several scholars have pointed out that the killing of the nestlings corresponds not so much to the abduction

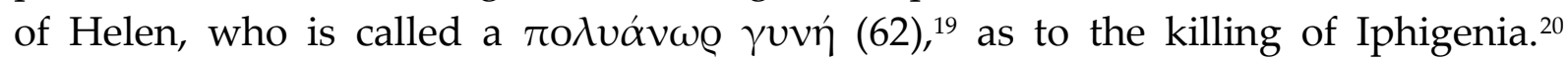
Building upon this observation, Ferrari has elaborated on the polysemy of the

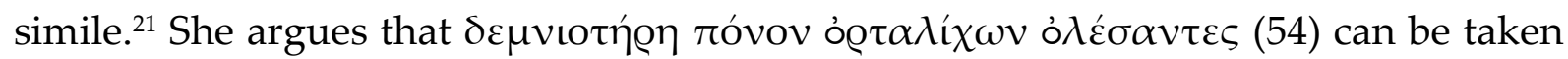
to mean "having destroyed the labor of nurture spent over the nestlings", adumbrating the death of Iphigenia. $\gamma$ óos, the lament over dead, ties in badly with the abduction of Helen who is still alive. Moreover, she notes, in late archaic and

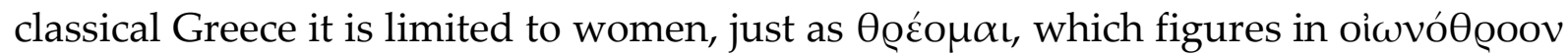
(56), is only applied to female voices. While not matching the tenor of the Atridae, the female articulation of lament evokes the choruses of the Choephoroi and Eumenides

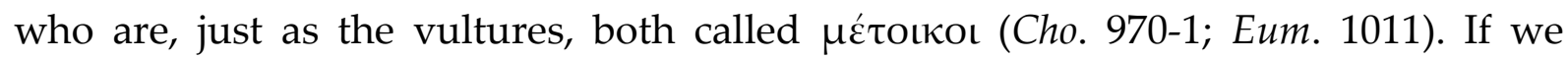
follow Ferrari's reading, then, besides representing the Trojan expedition, the vulture simile also alludes to the sacrifice of Iphigenia, the murder of Agamemnon, Orestes' revenge and his chase by the Erinyes.

The significance of metaphorical speech for choral intertemporality is also highlighted by the lion-parable in the second stasimon. In the first antistrophe, the chorus sings that the wedding-song for Helen at Troy was transformed into a dirge. In the second strophic pair (717-36), ${ }^{22}$ the chorus presents as a foil for this the parable of a lion-cub which was reared in a house with much love. Once grown up, the lioncub carried out a bloody massacre - "This thing they raised in their house was blessed/ by God to be priest of destruction" (735-6). Many temporal layers can be found in the lion-parable, the polysemy of which was elucidated by Knox in 1952. The chorus introduces the parable as a foil to Helen, who was welcomed and adored by the Trojans, but then caused them havoc. At the same time, some elements of the parable invite the recipient to see in the lion-cub also a cipher for other members of the royal family whose heraldic device was the lion. For example, the reference to marriage ceremonies in the phrase Év ßı́์ than Paris, and indeed Helen brought not only the Trojans, but also the Argives

\footnotetext{
${ }^{17}$ This may be fruitfully compared with the carpet scene which has raised the question whether or not Agamemnon is punished for stepping on the carpet. In itself, the stepping on the carpet may be harmless, but it is ominous as a sign for transgression.

${ }^{18}$ See Peradotto 1969 on cledonomancy in the Oresteia.

${ }^{19}$ Cf. Ferrari 1997: 30.

${ }^{20}$ Owen 1952: 65-6; Peradotto 1969: 13; Lebeck 1971: 8-9.

${ }^{21}$ Ferrari 1997: 30-5.

${ }^{22}$ Whereas the third and fourth strophic pairs consist mainly of iambics, the second pair is metrically more complex, combining glyconics, pherecreteans, lecythia and priapeans with dactylic half-verses. Cf. Fraenkel 1950: 328.
}

Published in: R. Gagné, M. Hopman (2013) Choral Mediations in Greek Tragedy, 78-99 
much ruin. ${ }^{23}$ Agamemnon, Clytaemnestra and Aegisthus are all called lions somewhere in the trilogy and fit the bill of the parable in one way or another.

Most strikingly, however, the parable not only blends together various events in the past, but it also extends to the future. It is Orestes who corresponds most closely to the lion-cub. His nurture is referred to several times in the trilogy; ${ }^{24}$ as a matricide "he showed forth with time the character of his parents" (727-8); and the

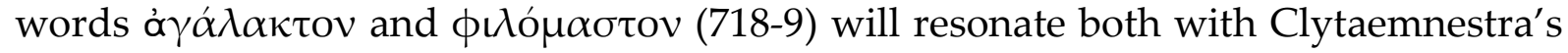
dream of breastfeeding a serpent which she had born (Cho. 526-9) and with her attempt to soften her son by baring her breast and reminding him of her nurture (Cho. 896-8). Thus, what for the chorus is an analepsis, an old story which highlights the past of the Atridae, works simultaneously for the audience as a prolepsis to a future still unknown to the chorus. The parable superimposes not only various past events, but also refers to the future. Together with the vulture simile in the parodos, the lion parable illustrates that metaphorical speech is particularly conducive to intertemporality. Like prophecies and signs, metaphors are highly polysemic and thereby lend themselves to bringing together various events.

Returning to the parodos, what can we conclude about the intertemporality of choral song? The chorus emphasizes its authority to narrate the Greek expedition to

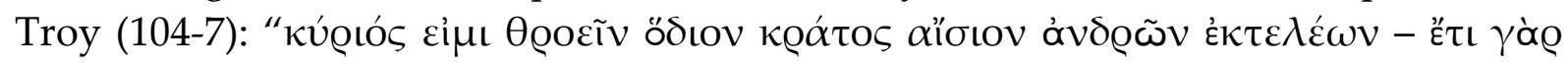

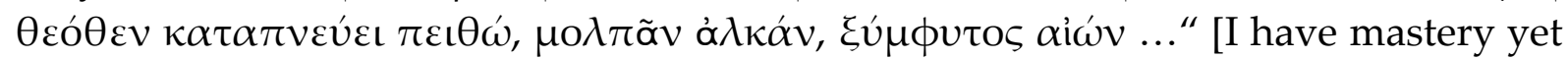
to chant the wonder at the wayside given to kings. Still by God's grace there surges within me singing magic grown to my life and power...].

Besides this claim and the metrical form of the passage - the numerous hexameters and the prominence of dactyls -, the embedding of direct speeches and the use of the Homeric vulture simile evoke the image of an epic bard; in some respects, however, the narrative power of the chorus is also reminiscent of that of a seer like Calchas in the Iliad, "who knew all things that were, the things to come and the things past" (Il. 1.70), or like Cassandra who will later go through both the past and future of the Atridae. ${ }^{25}$ Besides inserting references to the present into the account of the departure of the Greeks, the choreutae present the past as a panopticon in which various levels of time are tangled up with each other. While stressing the opaqueness of the future, they nonetheless play with the "future past" and, what is more, their words unwittingly adumbrate what is still to come. The indeterminacy of language and dissemination of meaning through signs raise the temporal complexity of the parodos. The various murders in the regal family of Argos, past and future ones, are projected one over another and reveal the merciless logic which underlies the lethal chain.

\footnotetext{
${ }^{23}$ Cf. Knox 1952: 19.

${ }^{24}$ Cf. Knox 1952: 23.

${ }_{25}$ Rutherford 2007: 3 rightly contrasts "the chorus's partial and uncertain exploration of the past, characterised by doubt and anxiety" with "the clear vision of the prophetess Cassandra into past and future". However, the extendend references to both future and past align the chorus with the prophetess who, as Rutherford admits expresses her insights in rather unclear terms.
}

Published in: R. Gagné, M. Hopman (2013) Choral Mediations in Greek Tragedy, 78-99 
A similar panopticon in which various times are made to intersect is set up in the first stasimon of the Agamemnon (355-488). This ode follows upon a conversation in which Clytaemnestra explains the significance of the beacon signs to the chorus and precedes the arrival of a messenger from Troy. This position firmly embeds it in the tension between confidence and insecurity that characterizes the chorus in the Agamemnon. The chorus starts in anapaests with an invocation of Zeus and Night who have wreaked havoc on Troy (355-69). The following lyrical part consists by and large of iambics, thereby formally harking back to the account of Iphigenia's sacrifice in the last three strophic pairs of the parodos. In an extended gnomic section (369-98), the old Argives stress that the gods do not pass over crimes (369-73). Who aims too high, will fall, whereas the wise one will content himself with little (374-80). Wealth provides no protection for those who violate the rules of Zeus (381-4), but sinners are invariably brought down by Ate and her child Peitho (385-7). A coin simile underscores that crimes do not remain undiscovered and leads to the final point that the gods are unmoved by the prayers of sinners (387-98). These general reflections are then illustrated by the case of Paris (399-408). After the abduction of Helen,

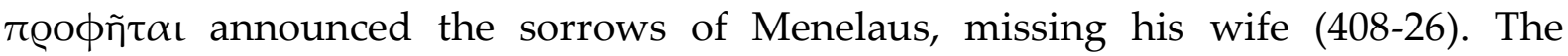
choreutae (or the $\pi \varrho 0 \phi \tilde{n} \tau \alpha \mathrm{s}$ ) add the sorrows of the Greeks who, shattered by the deaths in the ensuing war (427-47), have started criticizing the Atridae (448-57). This leads to a second gnomic section stating that the gods do not overlook success built upon injustice. Therefore the chorus wants neither to sack cities nor to be sacked (458-74). In the epode, the Argives call into question the reliability of the news about the fall of Troy (475-87).

Commentators have emphasized the change in the mood of the chorus. They first present confidently the fall of Troy as the divine punishment of Paris, but in the end, after elaborating on the opposition against the Atridae, cast doubts on whether Clytaemnestra's interpretation of the signs is correct. ${ }^{26}$ This wavering of the Argives between confidence and doubts converges with the blending of different times into one another that gives the ode an intricate temporal structure. The reflection on divine punishment in the first gnomic section is marked as a foil to the abduction of

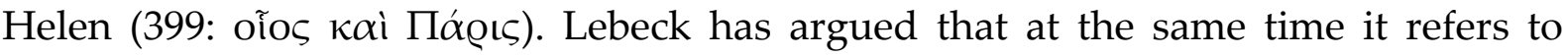
Agamemnon. ${ }^{27}$ While I am not entirely convinced that for example $\pi v \varepsilon o ́ v \tau \omega \nu \mu \varepsilon i ̃ \zeta o v$

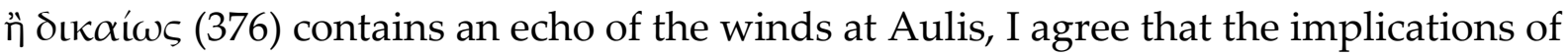
the first gnomic section for Agamemnon are made clear at the end of the ode, particularly by the second gnomic section. Both the preceding verses on the anger of the Greeks against the Atridae and the following wish neither to sack a city nor to be sacked $^{28}$ indicate that the second gnomic section is meant to shed light on

\footnotetext{
${ }^{26}$ E.g. Goldhill 1984: 48. See also Fletcher 1999: 32-3, who argues that "the chorus first presents the war in epic terms, then in more realistic terms" (33).

${ }^{27}$ Cf. Lebeck 1971: 37-44; Gantz 1983: 79 n. 46. See, however, the critique by Fletcher 1999: 34 with n. 16.

${ }^{28}$ The excessive praise in 468-9 anticipates the honours soon to be bestowed on Agamemnon by

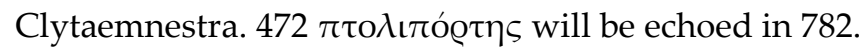

Published in: R. Gagné, M. Hopman (2013) Choral Mediations in Greek Tragedy, 78-99 
Agamemnon. Simultaneously, it echoes the first gnomic section and thereby bears out the similarities between Agamemnon and Paris: "The gods fail not to mark those who have killed many" (461-2) reworks the point that the gods punish mortals "who trampled down the delicacy of things inviolable" (371-2). The suspicion against too much success (468-9) echoes the warning against excess (376-80). The thunderbolt of Zeus (469-70) is reminiscent of the bolt which Zeus shot at Paris (363-6). Moreover, at

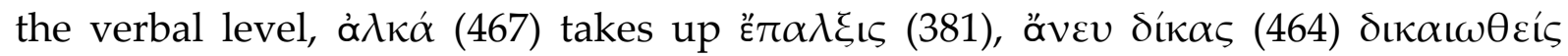

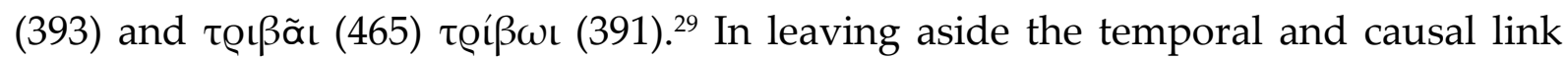
between the fates of Paris and Agamemnon, the chorus unveils a deeper level of significance which aligns the two opponents with one another.

Like the parodos, the first stasimon also contains a direct speech, namely the comment of the $\pi$ @oфñ $\tau$ เ. Besides the question of whether the speakers are in a marked sense "prophets" or, as I think is more likely, "spokesmen" in a general sense, $^{30}$ discussion has focused on the extension of the speech. The minimalist approach taken by Wilamowitz restricts the speech to the exclamation in the first two lines, ${ }^{31}$ others have it end after the prediction of the rule of a phantom (414-5), ${ }^{32}$ most

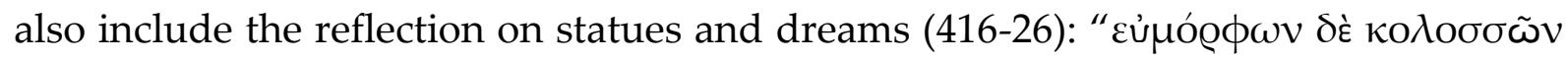

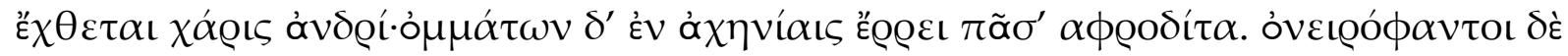

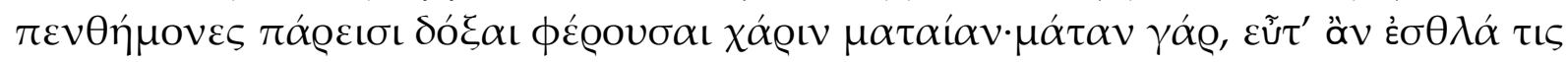

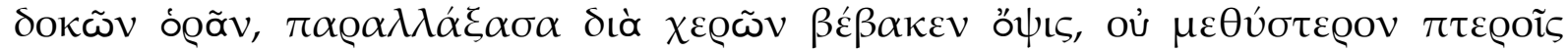
ỏ $\alpha \delta \delta$ ṽ $\sigma^{\prime}$ v์ $\tau$ vov $\kappa \varepsilon \lambda \varepsilon v ́ \theta$ oıs." [Her images in their beauty are bitterness to her lord now where in the emptiness of eyes all passion has faded. Shining in dreams the sorrowful memories pass; they bring him vain delight only. It is vain, to dream and to see splendors, and the image slipping from the arms' embrace escapes, not to return again, on wings drifting down the ways of sleep].

Lucia Athanassaki even argues that the speech extends until 455, therefore taking the sorrows of the Greeks as the object of a prediction. ${ }^{33}$ Instead of making a case for any of these suggestions, I would rather emphasize the vagueness of the extension of the speech which leads to a blending of the voices of the $\pi \varrho 0 \phi \tilde{n} \tau \alpha \iota$ with the voice of the chorus. The $\pi \varrho 0 \phi \tilde{n} \tau \alpha \iota$ as well as the chorus could elaborate on Helen's phantom governing Argos, the insufficiency of statues as a replacement of the beloved and the fleeting nature of dreams. Athanassaki's argument is not entirely cogent, but if we are willing to accept the futurity of several present tense forms without further marking, ${ }^{34}$ then it cannot be ruled out that even what the communis opinio takes to be a description by the chorus of the status quo is a prediction of the $\pi \varrho \circ \phi \tilde{n} \tau \alpha$. The vagueness of the extension of the speech also blurs the boundaries

\footnotetext{
${ }^{29}$ Two further echoes link the Greek opposition towards the Atridae to Menelaus' sorrow about the

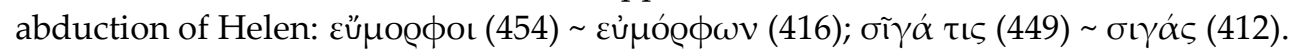

${ }^{30}$ For the bibliography s. Fletcher 1999: 34-5, who also opts for the translation "speakers"

31 Wilamowitz 1914a.

${ }^{32}$ Murray 21955 in his text; Thomson 1966: ad loc.; Lattimore 1953 in his translation. See also Campbell 1906 who uses the end of the strophe in 419 as demarcation of the direct speech.

33 Athanassaki 1993/1994.

${ }^{34}$ For this and other objections to Athanassaki's reading, see Fletcher 1999: 37.
}

Published in: R. Gagné, M. Hopman (2013) Choral Mediations in Greek Tragedy, 78-99 
between different times. ${ }^{35}$ Depending on the voice, the same words can be a description in the present or an analepsis or a prolepsis. Just as in the case of Paris and Agamemnon the similarity between their deeds, here the ambiguity of voice blends past and present into one another.

To sum up: in the first three choral songs of the Agamemnon, anachronies invoke past and future events that illuminate the present situation and resonate with each other. Some anachronies are full-fledged narratives as the report of the Greek departure in the parodos, some, for example the lion simile in the second stasimon, are only encapsulated in metaphors which through their highly polysemic character are very conducive to establishing intertemporality. Taken together, the anachronies embed the action in a broad temporal horizon, presenting a panopticon which refracts various levels of the heroic past.

\section{General Reflections: Blurring the Borderline between Past and Present}

The panopticon set up by the chorus is not limited to the heroic past, but also extends to the present of the performance. I will first return to the first three odes of the Agamemnon, which illustrate that general reflections and gnomai create a kind of meaning that is transtemporal and thereby blurs the borderline between the past of the play and the present of the performance. ${ }^{36}$ Then I will have a look at the third stasimon that can be read as a reflection on the limits of gnomai.

In the parodos it is particularly the so-called Hymn to Zeus that delimits the heroic past and opens it to the present of the performance. While featuring conventional elements of prayers and hymns such as the indefinite pronoun (160) and the conditional clause (161), the Hymn to Zeus does not, despite its name, fully qualify as hymn or prayer. ${ }^{37}$ Lacking an address in the second person, it is rather a reflection on Zeus, a reflection that, as we shall see, implies the reason for why it is not a prayer. Standing between Calchas' prophecy and the account of Iphigenia's death, the Hymn to Zeus has a retarding function in the narrative. The beginnings of the two first stanzas markedly juxtapose Zeus with human beings (160-2; 168-70):

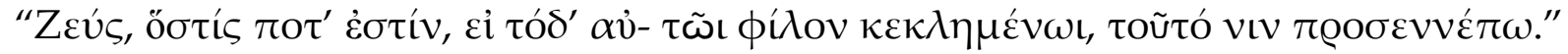
[Zeus: whatever he may be, if this name pleases him in invocation, thus I call upon him].

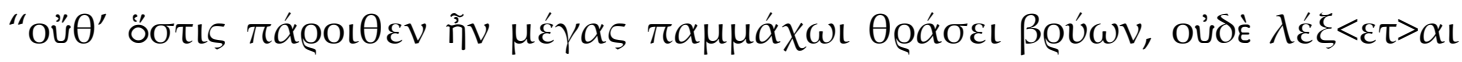

\footnotetext{
${ }^{35}$ Fletcher 1999: 38-42 elaborates on the ambiguity of the voice, but I am unconvinced by her argument that the dream sequence in 420-6 is "double-voiced", i.e. that it refers at the same time "to the past grief of Menelaus and the present grief of the Argives" (39). Indeed, the reflections in 420-6 are general, but coming after the sorrows of Menelaus it is natural to see in them a foil to them and not to the grief of the Argives which is clearly separated by the juxtaposition in 427-8.

${ }^{36}$ Cf. Cuny 2007 on general reflections in Sophocles, especially p. 165-176, in which she shows how the chorus uses general "pour rattacher les circonstances particulières de l'action à l'universel de la condition humaine."

${ }^{37}$ Cf. Smith 1980: 14. See also Fraenkel 1931, who elaborates on the background of ritual songs which can still be grasped in the parabasis of comedy. On hymns in tragedy, see below???
}

Published in: R. Gagné, M. Hopman (2013) Choral Mediations in Greek Tragedy, 78-99 


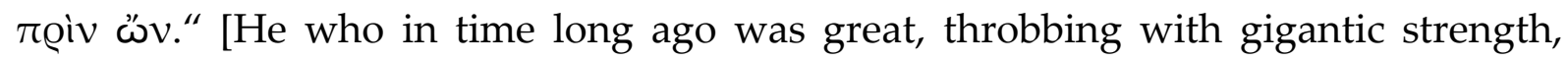
shall be as if he never were, unspoken].

In both cases, the process of signification is unstable, but whereas the reference to human beings can only be temporary because the object is subject to changes, the being of Zeus eludes signification. As Hans Blumenberg has pointed out, naming is an attempt at subjecting the named to some sort of control. ${ }^{38}$ The impossibility of naming Zeus, on the other hand, expresses his unapproachability which is the reason for the deviation from the form of the prayer. There is no point in addressing an inaccessible god, just as the chorus states earlier that no kind of sacrifice can prevent what has been fated (68-71).

Zeus' identity cannot be grasped by a name, but nonetheless the chorus sets

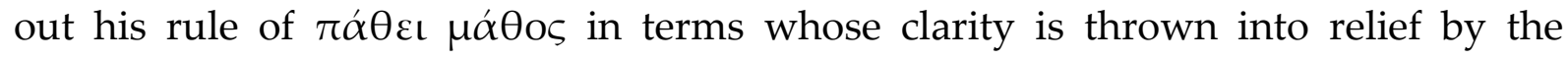
obscurity of the preceding and following stanzas. Zeus thus embodies at the same time the indeterminacy of meaning and provides an origin and a ground. ${ }^{39}$ The

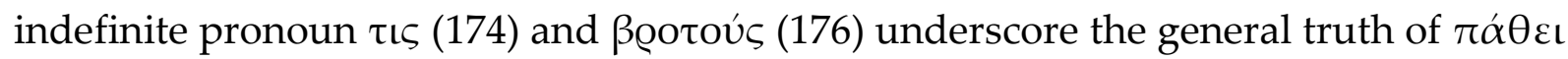
$\mu \alpha \dot{\theta}$ os which applies not only to the heroic world, but also to the present of the dramatic performance. Eduard Fraenkel, a scholar certainly free of any inclination towards fancy overtheorized readings, notes: "In the first stanza of the hymn

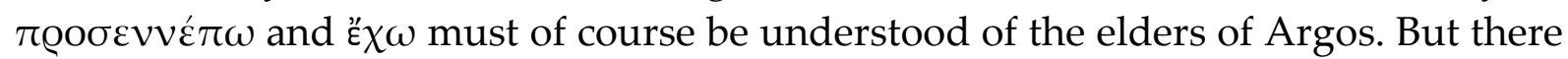
is no doubt that far more is included in that ' $\mathrm{I}$ '. The chorus speak also for the citizens of Athens, to whom they belong, and above all for the poet. It would be quite wrong to assume that the hymn does not form an organic part of the surrounding narrative...But it is true that eulogy of Zeus is intended to be valid beyond the limits of any particular situation." 40

General reflections and gnomai as the comments on "learning through suffering" blur the boundaries between "heroic vagueness" and democratic present. Whereas "zooming-devices" establish a link between past and present by embedding specific concepts and words of the world of the audience in the dramatic action, gnomai set up a horizon which embraces both "heroic vagueness" and democratic present. ${ }^{41}$ Thereby the heroic past is opened to the present of the performance: the

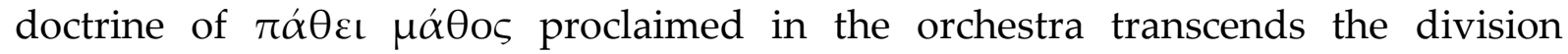
between stage and audience.

The gnomai in the first stasimon have a similar effect: the reflections on the justice of the gods and the danger of hybris apply not only to the heroic past, but also to the present of the audience. Of course, the present tense and gnomic aorist forms are uttered by the chorus in the frame of the dramatic action, but the content of the

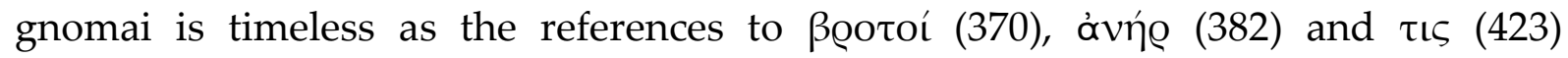
illustrate. There may be one "zooming-device" in the first stasimon which reinforces this transcendence of "heroic vagueness": The chorus mentions the ashes of the dead

\footnotetext{
38 Blumenberg 1979: 40-67.

${ }^{39}$ On Zeus as origin of meaning in the Agamemnon, see Goldhill 1984: 59-62.

40 Fraenkel 1950, II: 114.

${ }^{41}$ On the universal significance of the messages of tragedy, see Segal 1995: 15-26.
}

Published in: R. Gagné, M. Hopman (2013) Choral Mediations in Greek Tragedy, 78-99 
which are brought from Troy (438-44). Jacoby pointed out: "But nobody will seriously doubt that the singularity is due to a typical and deliberate anachronism after the Athenian custom which had been introduced but a few years earlier." 42 Normal Greek practice was to bury the war dead right on the spot, only the Athenians institutionalized some time after the Persian Wars a public burial of the war dead on the Kerameikos. Jacoby's point has not remained unchallenged, ${ }^{43}$ but I

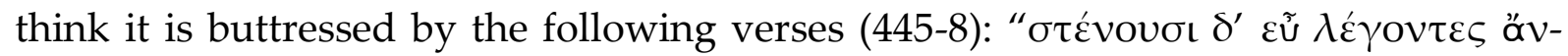

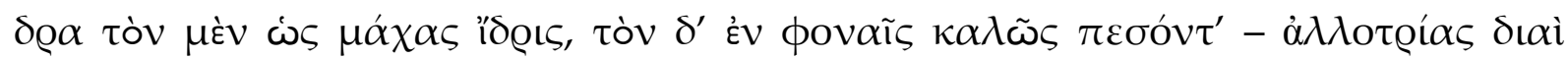

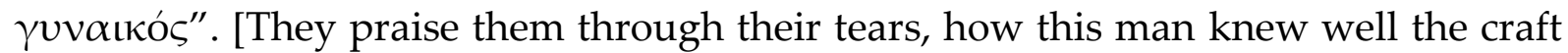
of battle, how another went down splendid in the slaughter: and all for some strange woman].

The chorus obviously sings here of individuals praising the dead, but it is not unlikely that the words of the $\varepsilon \tilde{u} \lambda \varepsilon \dot{\gamma} O v \tau \varepsilon \varsigma$ would also bring to mind the eulogies delivered on behalf of the polis. The reference to a distinct contemporary practice, the burial at Athens, would not have failed to draw the audience closer into the world of the play and to underscore the applicability of the gnomai to the present.

The second stasimon takes up and reworks some of the gnomai presented in the first. The reflection on the reproduction of hybris within a family harks back to the warning against excess: The juxtaposition of insatiable with modest men (374-80) is transformed into a juxtaposition of godless and just houses (758-762) and the contrast between poor and rich households (774-81) sharpens the notion that wealth does not protect against ruin (381-4). While the first stasimon zooms in on the impossibility for crimes to remain hidden, the second stasimon turns to the preceding phase of the $\pi \dot{\alpha} \theta \varepsilon \iota \mu \alpha \dot{\alpha} \theta$ os circle laid out in the parodos, the emergence of crimes. ${ }^{44}$ As in the other choral songs, the chorus sets up a frame of wisdom which serves primarily as foil to the dramatic action, but at the same time lays claim to a timeless truth which is still valid in the present of the performance. The imagery of

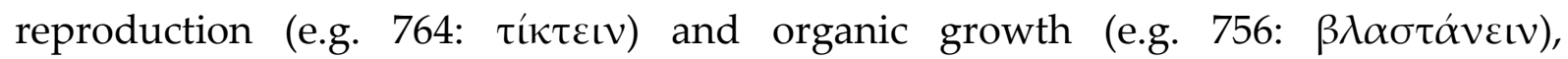
phenomena bound to no historical period, underscores the general applicability of the gnomai.

As these examples illustrate, the blending of different times into one another within "heroic vagueness" paves the way for bringing together the heroic past and the democratic present through general reflection. Projecting the dramatic action into a horizon which the audience shares with the heroes opens the past on stage to the present of the performance. This delimiting function of gnomai is reinforced by their presentation in choral songs. Of course, the choreutae remain part of the dramatic action, but the performance in the orchestra with an empty stage as well as the tradition of non-dramatic choral songs suggest that the audience would have no difficulties applying the reflections beyond the frame of the dramatic action.

\footnotetext{
42 Jacoby 1944: 44.

43 Gomme 1941-1981, II: 95: "I do not believe that he [i.e. Aeschylus] was given to deliberate anachronism of this kind." Against his objection, see Leahy 1974: 4-5.

44 This regressive movement in the odes of the Agamemnon is emphasized by Duchemin 1974: 123.
}

Published in: R. Gagné, M. Hopman (2013) Choral Mediations in Greek Tragedy, 78-99 
The third stasimon of the Agamemnon (975-1034) provides us with another set of gnomai that not only bridge the gap between the past of the play and the present of the performance, but also yield a reflection on the limits of gnomai. The anxiety and insecurity transparent in all the choral odes culminates in this final stasimon. ${ }^{45}$ The carpet scene leaves the chorus disturbed, trying to figure out the reason for their anxiety. ${ }^{46}$ In the first strophic pair (975-1000), the old men note that their disquiet ties in badly with the lucky return of the victorious army and pray that "all this expectation fade as vanity into unfulfilment, and not be" (998-1000). Searching for an answer, the chorus consider four gnomai in the second strophe (1001-16): first that sickness is a wall-to-wall-neighbour of health; second, that a fortunate man can hit an unseen reef; third, that a ship can be saved from drowning by throwing ballast over board; fourth, that abundant agricultural gifts of Zeus can free from famine. The second antistrophe (1017-33) starts with a fifth gnome stating that death is irreversible, a point evidenced by Asclepius who was punished for his attempt to revive Hippolytus. In closing, the chorus comment on their inability to express their feelings.

The gnomai take up the topic of wealth that has been the object of reflection

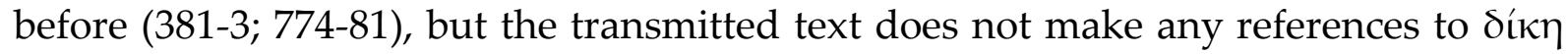
and its enforcement which loomed large in the gnomai of the preceding odes. ${ }^{47}$ In addition, the gnomai deviate from those in the other songs at a more general level. While also projecting experiences onto a timeless horizon, the gnomai in the third ode highlight the limits of such general reflections. The first two gnomai reveal that the chorus is turning towards the wisdom stored in gnomai to explain their sense of disquiet. They are worried despite good fortune - both the proximity of sickness to health and the reef unseen by the man with unswerving destiny draw attention to the fragility of good luck. While the third gnome takes up the naval imagery and envisages the possibility of fending off blows of fate, the fourth, significantly switching to the register of agriculture, even demonstrates that Zeus can turn bad into good situations. In harking back to the imagery of the first gnome, the metaphor

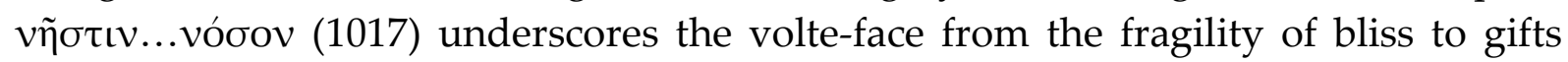
from Zeus. The fifth gnome, however, makes the series end on a somber note: whereas the other gnomai all dealt with reversals, the last points out the irreversibility of death. ${ }^{48}$

The quick sequence of gnomai, the variety of messages and the wealth of imageries show both the agitation of the chorus and their despair of finding an explanation for it. However, the plundering of wisdom's treasure-box does not

\footnotetext{
${ }^{45}$ On the metre, see Fraenkel 1950: 442-3.

${ }^{46}$ Cf. Taplin 1977: 316, who argues the other way around, namely that the agitation of the chorus testifies to the puzzling features of the preceding scene.

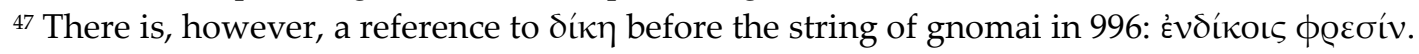

${ }^{48} \mathrm{As}$ far as the underlying tenor of the gnomai is concerned, I cannot follow Thalmann's otherwise lucid discussion of the ode (1985). I cannot see that they all treat some kind of excess followed by a reassertion of limits (112). The idea of reversal is more prominent than the notion of excess and also marks the difference from the fifth gnome.
}

Published in: R. Gagné, M. Hopman (2013) Choral Mediations in Greek Tragedy, 78-99 
satisfy the Argives, it leaves them even more distressed than before. The incapability of the gnomai to clarify their forebodings leads the chorus to a reflection on the relation between their heart and tongue (1025-33). ${ }^{49}$ The chorus' references to their own singing culminating in these verses underscore the failure of the gnomai and of language in general to express their feelings: In the first strophe, the elders speak of their song (979: $\dot{\alpha} 0 เ \delta \alpha$ ), in the second strophe their thymos chants a dirge (990-1: v $\mu \nu \omega \delta \varepsilon \tilde{\imath} \theta \varrho \tilde{\eta} v o v)$. The song may be unsolicited and unpaid for and the dirge may be performed by the self-taught thymos without a lyre, but nonetheless the elders use the proper vocabulary for song. After the failure to elucidate their anxiety with the help

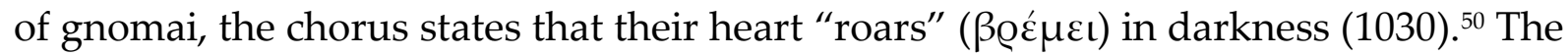
slip from song to inarticulate sound illustrates the disillusionment with language. ${ }^{51}$ While in the central ode of the Choephoroi the chorus will claim that it is "not

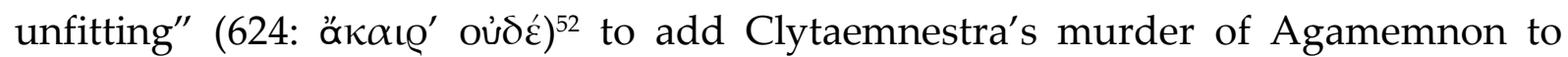
three mythical exempla for female violence against men, the old Argives harbour no

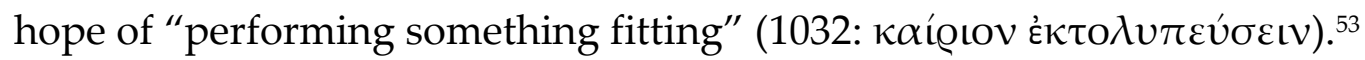

It is emblematic of the irony inherent in all choral odes of the Agamemnon that the gnomai have more significance than the chorus is aware of. ${ }^{54}$ The rich goods mentioned in the third gnome, for example, correspond to the exhibition of wealth in the carpet scene (948-9; 958-62), and it has even been argued that the "dark blood" in the last gnome resonates with the carpet and starts a whole series of references to spilling blood. ${ }^{55}$ It is however important to notice that even for the audience the significance of the gnomai is far from clear-cut. Does the irreversibility of death look back to the sacrifice of Iphigenia, as Scott believes, or does it anticipate the murder of Agamemnon, thus Judet de la Combe and Thiel?56 Gnomai set up a horizon which arches over both "heroic vagueness" and democratic present, but, as the third stasimon reveals, their power to elucidate a given moment is limited.

\section{Mise-en-abîme: Mirroring the Enactment of the Heroic Past}

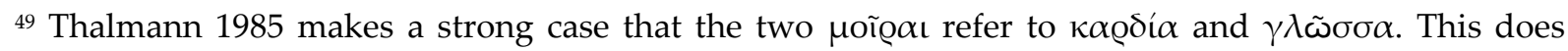
better justice to the syntax of the sentence and makes more sense in the context than the various attempts to identify the $\mu$ oĩo $\alpha$ with different "sorts". On these, see Thalmann 1985: 100-2; 117-8; Judet de la Combe 1982: 2.257-68. Against the thesis that the chorus fully knows the upcoming murder of Agamemnon and here is trying to explain why he does not warn their king, cf. Scott 1969: 342-3; Thalmann 1985: 101.

${ }^{50}$ As lectio difficilior, ßoع́ $\mu \varepsilon \mathrm{l}$, the reading of $\mathrm{F}^{2}$ and Triclinius adopted by Fraenkel, West, Bollack / Judet

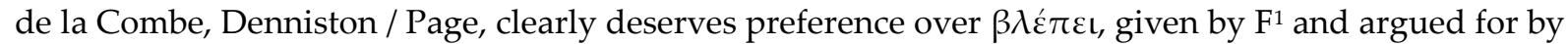

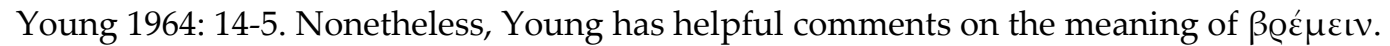

${ }^{51}$ The fifth gnome reveals yet another limit of song which cannot help resurrecting the dead (1021).

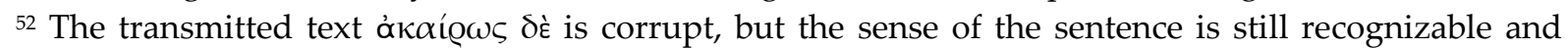
Stinton's conjecture (1979: 260), åk $\alpha \iota \varrho^{\prime}$ oủdè, adopted by West, convincing.

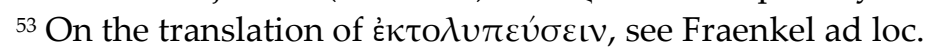

${ }^{54}$ On the capacity of general reflections for tragic irony, see Cuny 2007: 242-50.

${ }^{55}$ Goheen 1955: 118-9.

56 Scott 1969: 339; Judet de la Combe 1982; Thiel 1993: 282. See also Thalmann 1985: 117 on the ambiguity of this gnome and the different perspectives of audience and chorus.
}

Published in: R. Gagné, M. Hopman (2013) Choral Mediations in Greek Tragedy, 78-99 
The first stasimon of the Choephoroi illustrates an aspect of choral temporality in addition to the blending together of times and the transcending of "heroic vagueness" in gnomai. The evocation of myths as foil to the action can be read as a mise-en-abîme, defined as "toute enclave entrenant une rétention de similitude avec l'oeuvre qui la contient." ${ }^{57}$ That is, the relation between the heroic past enacted on stage and the present of the audience is mirrored in the relation between the "plupast" of the embedded myths and the heroic past.

Unlike most other analepses in the choral odes of the Agamemnon, the parable in the second stasimon harks back not to an earlier event of the story of the Atridae, but to something that is not part of the plot. Other than parables with anonymous characters, such analepses to extraneous events are given by embedded myths featuring specific characters. They are far more common in Euripides than in Aeschylus who, like Sophocles, has the chorus rather refer back to the prehistory of the plot $^{58}$ but the Oresteia offers one prominent case, the first stasimon of the Choephoroi that features three mythical exempla: Althaea, who killed her son by burning a brand on which his life depended (602-12); Scylla who was induced by a golden necklace from Minos to cut off the hair of her father and thereby to kill him (613-22); the Lemnian crime (631-8). The significance of these stories is manifold. At a

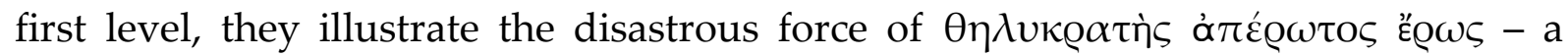
passion to which both humans and beasts are subject, be it "unnatural passion which conquers women", "unnatural female passion that conquers" or "unnatural passion that gives women power". ${ }^{59}$ Erotic aspects, however, are not prominent in the mythical exempla. They are missing entirely in the first story, as Althaea kills her son to take revenge for the murder of her brothers. In the second myth, the golden necklace may allude to the love for Minos which prompts Scylla to betray her father in later sources, ${ }^{60}$ but it is not referred to explicitly. Unlike the two other myths, the Lemnian crime is only mentioned, but not spelt out. Thus, the three myths are evoked as exempla not so much for the danger of female lust as for the consequences of female passion in general.

Nonetheless, the reference to the murder of Agamemnon (623-30) indicates that, more concretely, Althaea, Scylla and the Lemnian women serve as foils to Clytaemnestra. They are all women who, like Clytaemnestra, have killed the men closest to them, be it relatives or husbands. This use of the myths as foils to Clytaemnestra is not without irony, for the chorus' reflection on fearful phenomena seems to be triggered by her dream, but is then illustrated by female transgressions that parallel her own crime. The true horrors, it turns out, are not monsters like the snake to which Clytaemnestra gives birth in her dream, but women like Clytaemnestra herself.

\footnotetext{
${ }^{57}$ Dällenbach 1977: 18.

${ }^{58}$ Rutherford 2007 discusses lengthy narratives in choral odes. For a list, see Rutherford 2007: 33-4.

${ }^{59}$ On rich semantics of the phrase and these possible translations, see Garvie 1986: 599-602.

${ }^{60}$ Cf. Garvie 1986: ad 613-22.
}

Published in: R. Gagné, M. Hopman (2013) Choral Mediations in Greek Tragedy, 78-99 
This does not exhaust the significance of the myths. Anne Lebeck has made a strong case that they also refract the murders committed by Agamemnon and Orestes. ${ }^{61}$ The story of Althaea parallels the sacrifice of Iphigenia as the murder of a child by his parent, but reverses the gender relation. At the same time, it reproduces the mother-son relation of Clytaemnestra-Orestes, while exchanging perpetrator and victim. The Scylla-exemplum, on the other hand, is the murder of a parent by a child just like the killing of Clytaemnestra by Orestes, but again reverses the gender relation. Concerning the gender-relation, it mirrors Agamemnon-Iphigenia, while turning the direction of violence upside-down. "The first two exempla give back a looking-glass reflection of the parallel crimes committed by Agamemnon and Orestes, reversed in such a way that woman's treachery comes to the fore each time." 62 Thus, while homing in on Clytaemnestra's crime as female transgression, the myths also allude to the murders of Agamemnon and Orestes.

In Lebeck's eyes, the Lemnian story forms the climax in that it refers to two crimes. As Herodotus has it, there are two Lemnian crimes, first the murder of the Lemnians by their wives during the reign of Thoas, then, at a later time, the killing of the imported Athenian women by the Pelasgians of Lemnos (6.138). Thus, "the last exemplum reflects the mysterious way in which crime follows crime and one generation pays for another's wrong". ${ }^{63}$ The reference of the chorus is very vague and an allusion to the second crime cannot be ruled out, but given the focus on female transgressions the exemplum primarily evokes the assassination of the Lemnian men. The exemplum of the Lemnians owes its role as climax rather to the extent of the crime - not an individual, but all male inhabitants of an island are the victims - and to its close correspondence with Clytaemnestra's crime: while Althaea and Scylla kill their kin, the Lemnians equal Clytaemnestra in murdering their husbands.

The myths invoked by the chorus in the third stasimon are not directly linked to the plot of the Oresteia, but intersect with it through a complex set of similarities and differences. The "plu-past" duplicates the heroic past - it adds a past to the dramatic action just as the dramatic action stages a past for the audience. In both cases, a past is invoked which is not temporally linked to the present, but nonetheless sheds light on it. Just as the dramatic performances refract and rework aspects of the democratic present, the embedded myths serve as foils to the heroic past. The reference to the assault on Agamemnon makes explicit the foiling function of Althaea, Scylla and the Lemnian women, but, as we have seen, the significance of the foil is manifold. In the same way, the interaction of tragedy with contemporary reality is complex. Instead of giving clear cut answers, tragedy sheds light on current issues from various angles. While narratives and metaphors create a panopticon of different events and gnomai extend the song's significance to the world of the audience, mythical mirror stories illustrate how the tragic past interacts with the

\footnotetext{
${ }^{61}$ Lebeck 1967. See already Winnington-Ingram 1983 (1948): 115 n. 69.

62 Lebeck 1967: 183.

${ }^{63}$ Lebeck 1967: 183.
}

Published in: R. Gagné, M. Hopman (2013) Choral Mediations in Greek Tragedy, 78-99 
presence of the performance. They establish a meta-poetic dimension and endow the panopticon with a self-referential note.

\section{Ritual: Blending Together Past and Present}

The self-referential aspect of the chorus in Greek tragedy comes to the fore in choral comments on rituals they enact, as Albert Henrich has shown masterfully. ${ }^{64}$ Rituals are performed by the chorus within the frame of the dramatic action, but this dramatic performance takes itself place in the ritual setting of the Great Dionysia. Since choreutae are involved in ritual action both as characters in the internal communication system and as performers in the external communication system, their references to rituals which they perform tend to apply not only to the dramatic action, but also to the dramatic performance. Rituals can thus be seen as a point at which the times of the heroic past and the democratic present of Athens intersect. ${ }^{65}$ There is often a strong contrast between the perversion of rituals in the plays ${ }^{66}$ and the proper performance of the Great Dionysia. The closure of the Oresteia, on the other hand, provides us with a case where the rituals in the internal and external communications systems seem to merge and thereby to erase the boundary between the past on stage and the present of the audience: "In the last part of the Eumenides past, present, and future are curiously blended and fused." 67

As noted by commentators, the Eumenides is remarkable for opening the dramatic action towards the world of fifth-century Athens at the levels of space and time. ${ }^{68}$ Apollo sends Orestes from Delphi to Athens where the second part of the action takes place. ${ }^{69}$ The convergence of the space of the dramatic action with the space of the dramatic performance comes to the fore in the numerous deictic pronouns referring to "this city", "this country" and "this place" which work both in the internal and the external communication systems. ${ }^{70}$ At the level of time, three charter myths establish a close link to the present: the newly-founded court is presented as the Areopagus; the military help promised by Argos anticipates the contemporaneous alliance with Argos; the Erinyes are integrated into Athens as Semnai theai, goddesses with a cave sanctuary close to the Areopagus. ${ }^{71}$ This opening of the "heroic vagueness" towards the present of the performance is underscored by several marked references to the future of the three institutions. ${ }^{72}$ The "here and

\footnotetext{
${ }^{64}$ Henrichs 1994/1995; 1996.

${ }^{65}$ Cf. Henrichs 1994/1995: 68. See also Calame (this volume), who concentrates on the identity of the chorus and their multiple voices, whereas I focus on the temporal dimension of the choral performance.

${ }^{66}$ On the perversion of rituals in the Oresteia, see, e.g., Seaford 1994: 369-75.

${ }^{67}$ Solmsen 1949: 208.

${ }^{68}$ See, e.g., Chiasson 1999/2000.

${ }^{69}$ On the change of place, see Grethlein 2003: 219 n. 72.

${ }^{70}$ Cf. 834; 852; 884; 890; 902; 915.

${ }^{71}$ Cf. Grethlein 2003: 216-8.

${ }^{72}$ Cf. Grethlein 2003: 219-22.
}

Published in: R. Gagné, M. Hopman (2013) Choral Mediations in Greek Tragedy, 78-99 
forever"73 of the charter myths renders the closure of the Oresteia particularly significant for the Athenian audience.

Two ritual actions go even further and not only open the internal to the external communications systems, but force them to merge. When Athena manages to appease the Erinyes by offering them honour and cult in Athens, they ask her what "spell to put on this country" (902) and then present a song of benedictions in an amoibaion with the goddess (916-1020). ${ }^{74}$ Such hymns invoking the goodwill of gods seem to have been a common feature in various settings in archaic and classical Greece. ${ }^{75}$ The blessings at the end of the Eumenides are embedded in the dramatic action, but since they are directed at the very polis which organizes the dramatic festival, and since they are directed towards a future including the present, they apply to the Athens of the performance as well as to the Athens within the action. Hence, the ritual on stage fuses with the ritual of the stage, the internal and external communication systems are blended together and the borderline between heroic past and democratic present is blurred.

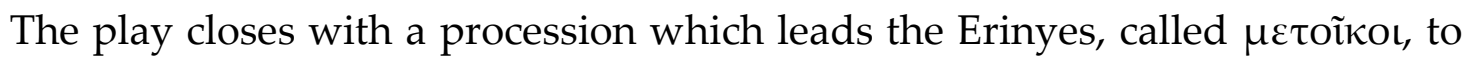
their new home. ${ }^{76}$ Particularly the red robes put on by the chorus evoke the procession of the Panathenaea in which the metics wore red..$^{77}$ The zooming in on a ritual detail of a contemporaneous festival opens the dramatic action towards the present of the Great Dionysia, but I think the procession may have challenged the boundary between dramatic action and performance more profoundly. As described by Athena, the procession is also joined by the Athenian people. It is possible that the Athenian people were represented by actors on stage, it is possible that they were not. In the latter case, reinforced by the opening of the heroic past to the present and by the blending together of the two, the audience could have represented itself, the people of Athens. Such an integration of the audience into the play would have made the presence of the Athenian people an act of representation, fusing the internal communication system entirely with the external. This scenario is nicely complemented by Wilamowitz' suggestion that the audience joined in the ololygmos. ${ }^{78}$ At the end of the Oresteia, the spatial convergence of action and performance and the temporal opening of the heroic past towards the future ground provide the ground on which the time of the rituals enacted on stage merges with the ritual time of the stage.

\footnotetext{
${ }^{73}$ Chiasson 1999: 149.

${ }^{74}$ The prominence of lekythia together with iambics and trochaics align the singing of the chorus with the second stasimon (490-565). For a metrical analysis, see Sommerstein 1989: 292-3.

${ }^{75}$ Cf. Jaeger 21936: 325; Solmsen 1949: 211. On such hymns in ancient Greece in general, see Norden 1939: 268-74. On hymns in Greek tragedy in general, see Furley / Bremer 2001: 273-9.

${ }^{76}$ On the procession, see Sommerstein 1989: ad 1021-47. On the hymn of the female servants as an “apopemptic hymn", see Furley / Bremer 2001, I: 295-6.

77 Cf. Headlam 1906; Thomson ad 1027-1031; Bowie 1993: 27-9.

${ }^{78}$ Wilamowitz 1914b: 185. See also Belfiore 1992: 27. On the ritual dimension of the refrain, see Moritz 1979: 209-12.
}

Published in: R. Gagné, M. Hopman (2013) Choral Mediations in Greek Tragedy, 78-99 


\section{Conclusion}

Tragedy makes the heroic world confront the contemporary reality of fifthcentury Athens. The concept of "zooming-devices" has elucidated an important mechanism by which "heroic vagueness" is rendered significant for the audience in the theatre of Dionysus. The reference to the urns of ashes returning from Troy in the first stasimon of the Agamemnon and the allusions to the Panathenaea in the closing of the Eumenides illustrate that choral odes can "zoom in" on the world of the audience. The majority of "zooming-devices", however, occur in epeisodia, whereas the language of choral odes marks a gap between the world of the heroes and the everyday-world of the audience. The "intertemporality" of the chorus, the temporality by which the chorus mediates between stage and audience, works along different lines. We have seen that the chorus of the Agamemnon in their songs create a panopticon in which events cast in "heroic vagueness", from various levels of the past including the future past, shed light on one another, partly by intention of the characters of the chorus, partly beyond their means of understanding. On the ground of this dynamic interaction between past, present and future, the delimitation of time is extended beyond the "heroic vagueness" through gnomai which lay claim to timeless validity. The practice of singing and listening to gnomai in extra-dramatic choral performances would have made it hard for Athenians not to consider the general reflections in tragic odes also outside of their dramatic context.

In addition to creating a horizon which embraces the heroic past as well as the democratic present, the choral odes also provide a mise-en-abime for the dynamic interaction between the past of the dramatic action and the present of the performance. In the first stasimon of the Choephoroi, the chorus invokes three myths as a foil to the murder of Agamemnon. The significance of the embedded myths for the dramatic action is manifold just as tragedy provides no clear-cut messages for the present. In illustrating the hermeneutic possibilities and limits of myth, the choral odes underscore the reflective character of tragedy.

The merging of the rituals and the blending together of internal and external communication systems at the end of the Eumenides is unusual for Greek tragedy. ${ }^{79}$ It nevertheless alerts us to the special temporality of ritual. Ritual transcends linear time and establishes a time of itself, a time-out beyond the everyday world. The Great Dionysia provide such a time-out in which the democratic present can enter into a dialogue with the heroic past. In combining the roles of dramatic characters and ritual performers, the chorus is more essential to this dialogue than its traditional form may reveal at first sight. We can even say that traditional features, particularly gnomai and rituals, are at the core of the choral contribution to the relevance of "heroic vagueness" to the democratic world of the fifth century.

\footnotetext{
${ }^{79}$ Compare for example the binding song in the Eumenides as analyzed by Calame (this volume). Calame notes a subtle oscillation between the ritual and heroic identities of the chorus, but there is not the kind of merging that we can observe at the end of the Eumenides: the intention of the Erinyes to bind Orestes is limited to the world of the play.
}

Published in: R. Gagné, M. Hopman (2013) Choral Mediations in Greek Tragedy, 78-99 
Works cited:

Athanassaki, Lucia 1993/4. 'Choral and Phonetic Discourse in the First Stasimon of the Agamemnon', CJ 89:149-62.

Barrett, James 2007. 'Aeschylus', in De Jong, Irene and Nünlist, René (eds.) Time in Ancient Greek Literature. Leiden: Brill, pp. 255-73.

Belfiore, Elisabeth 1992. Tragic Pleasures. Aristotle on Plot and Emotion. Princeton: Princeton University Press.

Bers, Victor 1997. Speech in Speech. Studies in incorporated 'Oratio recta' in Attic drama and oratory. Lanham: Rowman \& Littlefield.

Blumenberg, Hans 1979. Arbeit am Mythos. Frankfurt am Main: Suhrkamp.

Bollack, Jean and Judet de La Combe, Pierre (eds.) 1981/1982. L' Agamemnon d'Eschyle. Le texte et ses interprétations. Lille: Publications de l'Université.

Bowie, Angus M. 1993. 'Religion and Politics in Aeschylus' Oresteia', CQ New Series 43:10-31.

Calame, Claude 1999. 'Performative Aspects of the Choral Voice in Greek Tragedy: Civic Identity in Performance', in Goldhill, Simon and Osborne, Robin (eds.) Performance Culture and Athenian Democracy. Cambridge: Cambridge University Press, pp. 125-53.

Campbell, Archibald Young 1906. The Agamemnon of Aeschylus. Liverpool: University Press of Liverpool.

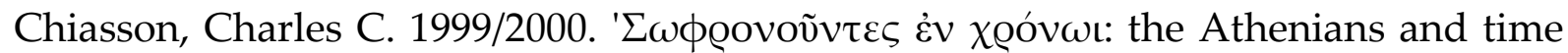
in Aeschylos' Eumenides', The Classical Journal 95:139-61.

Court, Barbara 1994. Die dramatische Technik des Aischylos. Stuttgart.: Teubner.

Cuny, D. 2007. Une leçon de vie. Les réflexions générales dans le théâtre de Sophocle. Paris.

Dällenbach, Lucien 1977. Le récit spéculaire. Essai sur la mise en abyme. Paris: Du Seuil.

Denniston, John D. and Page, Denys Lionel (eds.) 1957. Aeschylus. Agamemnon. Oxford: Clarendon Pr. 
Duchemin, Jaqueline 1967. 'Le déroulement du temps et la composition de l'Agamemnon d'Eschyle', Information littéraire 19:165-72.

Duchemin, Jaqueline 1974. 'Du Lyrisme à la tragédie. Reflexions sur l'Agamemnon et les Perses d'Eschyle', in Heller, John L. (ed.) Serta Turyniana. Studies in Greek Literature and Palaeography in Honor of Alexander Turyn. Urbana: University of Illinois Press, pp. 122-42.

Easterling, Patricia E. 1985. 'Anachronism in Greek tragedy', Journal of Hellenistic Studies 105:1-10.

Easterling, Patricia E. 1997. 'Constructing the heroic', in Pelling, C. (ed.) Greek Tragedy and the Historian. Oxford: Clarendon Press, pp. 21-37.

Ferrari, Gloria 1997. 'Figures in the Text: Metaphors and Riddles in the Agamemnon', CPh 92:1-45.

Ferrari, Walter 1938. 'La parodos dell' "Agamemnone"', ANSP 7:355ff.

Fletcher, Judith 1999. 'Choral Voice and Narrative in the First Stasimon of Aeschylus Agamemnon', Phoenix 53:29-49.

Foley, Helene 2003. 'Choral Identity in Greek Tragedy', CPh 98:1-30.

Fraenkel, Eduard 1931. 'Der Zeusmythos im Agamemnon des Aischylos', Philologus 86:1-17.

Fraenkel, Eduard (ed.) 1950. Aeschylus. Agamemnon. I-III. Oxford: Clarendon Press.

Furley, William D. and Bremer, Jan M. 2001. Greek Hymns. Selected Cult Songs from the Archaic to the Hellenistic Period. I-II. Tübingen: Mohr Siebeck.

Gantz, Timothy 1983. 'The Chorus of Aischylos' Agamemnon', HSCPh 87:65-86.

Garvie, Alexander F. 1986. Aeschylus. Choephori. Oxford: Clarendon Press.

Genette, Gérard 1972. Figures III. Paris: Seuil.

Goheen, Robert F. 1955. 'Aspects of Dramatic Symbolism. Three Studies in the Oresteia', AJPh 76:113-37.

Goldhill, Simon 1984. Language, Sexuality, Narrative. The Oresteia. Cambridge: 
Cambridge University Press.

Gomme, Arnold W., Andrewes, Anthony and Dover, Kenneth James 1941-1979. A Historical Commentary on Thucydides. I-V. Oxford.: Clarendon Press.

Gould, John 1996. 'Tragedy and Collective Experience', in Silk, Micheal (ed.) Tragedy and the Tragic. Oxford: Clarendon Press, pp. 217-43.

Grene, David (ed.) 1953. Aischylos. I, Oresteia. Transl. and with an introd. by Richmond Lattimore. Chicago.

Grethlein, Jonas 2003. Asyl und Athen. Die Konstruktion kollektiver Identität in der griechischen Tragödie. Stuttgart, Weimar: Metzler.

Grethlein, Jonas and Krebs, Christopher (eds.) forthcoming. Time and Narrative in Ancient Historiography. The 'Plupast' from Herodotus to Appian. Cambridge: Cambridge University Press.

Headlam, Walter 1906. 'The Last Scene of the Eumenides', JHS 26:268-77.

Henrichs, Albert 1994/5. "'Why Should I Dance?" Choral Self-Referentiality in Greek Tragedy', Arion 3:41-55.

Henrichs, Albert 1996. 'Dancing in Athens, Dancing on Delos. Some Patterns of Choral Projection in Euripides', Philologus 140:48-62.

Herington, John 1985. Poetry into Drama. Early Tragedy and the Greek Poetic Tradition. Berkeley: University of California Press.

Holtsmark, Erling B. 1966. 'On Choephoroi 585-651', CW 59:215-6; 51.

Jacoby, Felix 1944. 'Patrios nomos. State burial in Athens and the public cemetery in the Kerameikos', JHS 64:37-66.

Jaeger, Werner 1936. Paideia. I. Berlin: De Gruyter.

Judet de La Combe, Pierre 1982. L'Agamemnon d'Eschyle. Deuxième Stasimon. Accueil d'Agamemnon. Troisième Stasimon . Dernier Stasimon. Lille: Publ. de l'Univ.

Knox, Bernhard M. W. 1952. 'The Lion in the House (Agamemnon 717-36 [Murray])', CPh 47:17-25.

Lattimore, Richmond 1953. The Oresteia. Chicago: University of Chicago Press. 
Leahy, D. M. 1974. 'The Representation of the Trojan War in Aeschylus' Agamemnon', AJPh 95:1-23.

Lebeck, Anne 1967. 'The First Stasimon of Aeschylus' Choephori: Myth and Mirror Image', CPh 62:182-5.

Lebeck, Anne 1971. The Oresteia. A Study in Language and Structure. Washington: Harvard University Press.

Moritz, Helen E. 1979. 'Refrain in Aeschylus: Literary Adaption of Traditional Form', CPh 74:187-213.

Murray, Gilbert 1955. Aeschyli septem quae supersunt tragoediae. Oxford: Clarendon.

Norden, Eduard 1939. Aus altrömischen Priesterbüchern. Lund: Gleerup.

Owen, E. T. 1952. The Harmony of Aeschylus. Toronto: Clarke, Irvin.

Peradotto, John J. 1969. 'Cledonomancy in the Oresteia', AJPh 90:1-21.

Rutherford, Richard B. 2007. "'Why should I mention Io?" Aspects of Choral Narration in Greek Tragedy', Cambridge Classical Journal 53:1-39.

Scott, William C. 1969. 'The Confused Chorus (Agamemnon 975-1034)', Phoenix 23:33646.

Seaford, Richard 1994. Reciprocity and Ritual. Homer and Tragedy in the Developing CityState. Oxford: Clarendon Press.

Segal, Charles 1995. 'Classics, ecumenicism, and Greek tragedy', TAPhA 125:1-26.

Sidgwick, Arthur 1881. Aeschylus. Agamemnon. Oxford: Clarendon Press.

Sier, Kurt 1988. Die lyrischen Partien der Choephoren des Aischylos. Text, Übers., Kommentar. Stuttgart: Steiner.

Smith, Peter M. 1980. On the Hymn to Zeus in Aeschylus' Agamemnon. Ann Arbor: Scholars Press.

Solmsen, Friedrich 1949. Hesiod and Aeschylus. Ithaca: Cornell University Press.

Sommerstein, Alan A. 1989. Aeschylus. Eumenides. Cambridge: Cambridge University

Published in: R. Gagné, M. Hopman (2013) Choral Mediations in Greek Tragedy, 78-99 
Press.

Sourvinou-Inwood, Christiane 1989. 'Assumptions and the Creation of Meaning. Reading Sophocles' Antigone', JHS 109:134-48.

Stinton, Thomas C. 1979. 'The First Stasimon of Aeschylus' Choephori', CJ New Series 29:252-62.

Taplin, Oliver 1977. The Stagecraft of Aeschylus. The Dramatic Use of Exits and Entrances in Greek Tragedy. Oxford: Clarendon Press.

Thalmann, William G. 1985. 'Speech and Silence in the Oresteia 1: Agamemnon 10251029', Phoenix 39:99-118.

Thiel, Rainer 1993. Chor und tragische Handlung im "Agamemnon" des Aischylos. Stuttgart: Teubner.

Thomson, George (ed.) 1938. The Oresteia of Aeschylus. I-II. With an introduction and commentary, in which is included the work of the late Walter Headlam. Cambridge: Cambridge University Press.

Thomson, George (ed.) 1966. The Oresteia of Aeschylus. I-II. With an introduction and commentary, in which is included the work of the late Walter Headlam. Amsterdam: Hakkert.

Vernant, Jean-Pierre 1990. 'Tensions and Ambiguities in Greek Tragedy', in Vernant, Jean-Pierre and Vidal-Naquet, Pierre (eds.) Myth and Tragedy in Ancient Greece. New York: Zone Books, pp. 29-48.

West, Martin L. 1998. Aeschyli Tragoediae cum incerti poetae Prometheo. Stuttgart: Teubner.

Wilamowitz-Moellendorff, Ulrich von 1914. Aischylos. Interpretationen. Berlin: Weidmann.

Wilamowitz-Moellendorff, Ulrich von 1914. Aeschyli Tragoediae. Berlin: Weidmann.

Winnington-Ingram, Reginald P. 1983. Studies in Aeschylus. Cambridge.: Cambridge University Press.

Young, Douglas C. 1964. 'Gentler medicines in the Agamemnon', CQ 58:1-23. 